\title{
ARTICLES \\ ISLAMIC FAMILY LAW REFORM: \\ PROBLEMS AND PROSPECTS
}

\author{
Mohammad Hashim Kamali*
}

\begin{abstract}
This article features with a general characterisation of the Qur'ān with reference to family law and gender equity. Its main purpose is to visualise the broader picture of qur'ānic dispensations and the manner they are manifested in the sharī ah. A brief outline of the higher objectives (maqāșid) on family welfare and reproductive health is also discussed.
\end{abstract}

\section{Introductory Remarks}

The fiqh discourse on women and family is more often focused on specific rules and formulations rather than the broader objectives of Islamic law. Due to historical reasons and the fact that the higher objectives (maqāssid) as a branch of the shari 'i $a h$ developed long after the figh of the leading schools, one often notes that this subject is expressive also of the concern that contemporary ijtihäd in conjunction with outstanding and unresolved issues should manifest the interests of both continuity and change - such that the law moves abreast with the realities of social change without compromise on basic values.

We should naturally value the learned contributions of the past 'ulama ' without, however, indulging in indiscriminate imitation (taqlīd) of their views. Furthermore, when turning to Qur'ān and Sunnah for guidance, one should remember that this ought to be a meaningful recourse and not simply one of reading the broader guidelines of the scripture under the influence again of scholastic opinion - as is often wittingly or unwittingly done. I may quote here the insightful observation of Shaykh Yūsuf al-Qaraḍāwī who wrote in an essay he authored on moderation versus extremism with reference to women: "It is an obligation of the ummah to protect women from the excesses of the Muslim juristic legacy of the past and those of the modern West, both of which strip women of their essential humanity." This only shows that the twentieth-century legislative reform of Islamic family law that

* Mohammad Hashim Kamali is the Chairman and CEO of IAIS Malaysia. 
corrected some of the imbalances of the traditional fiqh was well-conceived and marked a move in the right direction. Yet it may be added here that some of the reform measures so introduced were more comprehensive than others in as much as not all Muslim countries cannot be placed under one and the same category.

Prevailing conditions of gender justice and family welfare tend to vary widely from one country to another. Some Muslim countries, including Malaysia, have taken strident steps towards reforming the Islamic family law more widely compared to other Muslim countries. Yet challenges still remain and the general picture in many countries of Asia and Africa is marred by the tenacious hold of prejudicial customs of tribal origin, and the resistance also of conservative opinion to reform. Whereas some aspects of the family law have undergone healthy adjustment, others are still wanting of fresh scrutiny and $i j t i h \bar{a} d$-oriented solutions. There were a few instances also in some countries, including Malaysia, of negative reform which, due to the renewed strength of conservative opinion in society, the ruling party and government, some of the more egalitarian provisions of the law on gender equity were revised and replaced by more restrictive measures.

\section{The Qur'ānic Outlook: An Overview}

The Qur'ân is supportive of the moral autonomy of the individual and makes it a responsibility, both of the individual and community, to strive for improvement when they see the prospects of securing it; for "God will not change their condition unless they decide to change it themselves" (13:11). The latter portion of this verse can also be read to mean 'unless they change what is within themselves', an inner transformation, in other words, through enlightenment and reform is needed in the first place. The Qur'ān also portrays an essentially positive outlook on life in this world that can be improved and enriched through correct guidance (hidāyah), selfdiscipline and refinement (tazkiyah) that ultimately lead to felicitation and success (falāh). The text altogether conveys a success-oriented outlook, transformation and reward for those who seek to achieve them. Islamic theology and jurisprudence have internalised these guidelines in their respective concepts of renewal (tajdīd), reform (ișlāh) and ijtihād.

Among the salient ethical norms of Islam that merit attention in the planning of a reform agenda for family law, one is 'the urging of what is recognised and approved and the restraining from that which is rejected' - al-amr bi 'l-ma 'rüf wa 'l-nahy 'an al-munkar. This is a qur'ānic principle of universal import and application to almost all aspects of family life, social relations, law and governance, and should naturally provide a basic frame of reference for family law reform.

The moral essence of qur'ānic laws is broadly reflected in their guidelines on permissibility and prohibition (halāl, harām), recommended (mandūb) and 
reprehensible (makrūh) as well as its conceptions of justice, fairness and being good to others ('adl, qist and ihsān). There is much emphasis on compassion (rahmah) and moderation (wasatiyyah, $i$ 'tida $\bar{l}$ ) that shuns extremism and excess and pays attention to the ways and means that attain moderation and justice in almost all aspects of human conduct. The cosmological outlook of the Qur'ān on human equality should naturally be reflected in the legal rulings of the shari 'ah on gender equality, marital relations and family life, civil transactions, crimes and punishments and so on. The Qur'ān often provides room for fresh insight and interpretation as a great deal of its textual rulings consist of general ( 'a $\bar{m} m$ ) declarations, and principles that are amenable to particularisation, as opposed to the specific ( $k h \bar{a} s \underline{s}$ ) of self-contained variety that may require no interpretation and $i j t i h \bar{a} d$. Without wishing to enter technical details, I draw attention only to two qur'ānic verses that accommodate a degree of latitude and selection which has, however, been almost totally ignored in the conventional theory of $i j t i h \bar{a} d$. The first of these refers to situations where the Qur'ān enables its readers to select between its differential rulings, or indeed select one out of a plurality of available interpretations of one and the same text for purposes of implementation and ijtihād:

And give good tidings to those of My servants who listen to the word (qawl) and follow the best of it (ahsanahu). Those are the ones God has guided and endowed with understanding. (Qur'ān 39:18)

Qawl could here refer to the word of God, namely the Qur'ān, or any other speech, but since it occurs in the form of a general declaration ( 'âmm) we retain the same to say that it subsumes all speech, including God's own illustrious speech. Muslim jurists and commentators have given this verse an interpretation, however, which pays little attention to the element of selection that is quite obvious in its import and wording. The verse clearly tells us that we listen to the word but follow the best of it. The question the jurists have posed here is whether one can distinguish between the words of God which are best (ahsan), as opposed to those which are merely good (hasan), and the answer given is in the negative. Some commentators have suggested that the reference here is only to conduct and how one acts on or implements the textual guidance, especially when different options can be visualised, such as between punishment and forgiveness and the like. ${ }^{2}$ In such circumstances, the judge and the learned scholar (mujtahid) should choose the best meaning or course of action, but beyond that we do not have the flexibility to determine what is the best or second best, as it were, in the speech of God. My own reservation about this line of analysis is that it leaves out the obvious message of the verse, which is that when different verses or dispensations are found in the Qur'ān that could guide a certain course of conduct, interpretation and ijtihād, one should be able to select that which secures justice and people's welfare in the best possible 
way. I am not here engaging into the specifics of the rules of interpretation found in the science of the sources (i.e., the $u s \underline{u} l$ al-fiqh) but merely to say that one ought to be able to take advantage of the elements of flexibility and selection the Qur'ān has openly authorised in full cognisance of God's hikmah and wisdom, without necessarily engaging in restrictive questioning and interpretations that the text itself may not even sustain.

The second passage I discuss here concerns the cosmological outlook of the Qur'ān and its vision of human equality. The passage in question opens the fourth sürah (al-Nis $\left.\bar{a}^{\prime}\right)$ and provides in a general address to the people:

O mankind, keep your duty (ittaqū) to your Lord, Who created you from a single soul ( $m$ in nafs ${ }^{\text {in }}$ wăhidat ${ }^{\text {in) }}$ ) from which He created its mate and from them countless men and women; keep your duty to your Lord through Whom you demand your mutual (rights), and keep your duty to the wombs (that bore you): for Allah ever watches over you. (4:1)

It is significant to note that in the key phrase $\left(\min n a f s^{i n}\right.$ wăhidat $\left.{ }^{\text {in }}\right)$, the word nafs (soul) is a feminine word. This phrase also occurs in toto elsewhere in the Qur'ān (39:6) and both verses convey the message that human beings originate in nafsin wăhidat ${ }^{\text {in }}$, the single feminine soul. And then the twin or mate that ensues from that soul is referred to as $z a w j$, which is a masculine word suffixed by a feminine pronoun $(z a w j a h \bar{a})$. The origin of human creation from a female and a male so expounded in the Qur'ān contemplates human equality and fraternity, but also reproductive continuity through the womb and marriage. The goal and purpose of God's creation in that order is indicated in another verse, which recapitulates the shared lineage of homo sapiens but adds: "It is He Who created you from a single soul and made out of it its mate that he might dwell with her (in love; Qur'ān 7:189)." Love and tranquillity thus signify the higher purposes of marriage within the larger continuum of human equality. ${ }^{3}$

It is noteworthy also that absolute human equality opens the chapter about women, al-Nis $\bar{a}^{\prime}$, and that the chapter then proceeds to expound most of the detailed rulings concerning marriage. Marriage regulations should, in other words, be guided by the principle of human equality.

Law in Islam is a carrier, for the most part, of its ethical norms and although certain lines of distinction are recognised between morality and law for purposes of adjudication and enforcement, essential harmony between the legal and ethical norms is necessary to ensure continuity of values and better prospects of public acceptance and enforcement. When the nexus between the law and ethics is broken, or when obvious discrepancies set in to disturb the desired equilibrium between them, measures should be taken to restore the balance. Some of the specific rulings of fiqh are often exposed to questions as to whether they stand in a state of tension with the broader guidelines of Islam on equity and justice. The decline of ijtihād 
over a longer stretch of history, and the influence of entrenched patriarchal customs are responsible for many of the unresolved issues of Islamic family law. It is now widely seen that some of the figh rulings that bear the vestiges of medieval society values have yet to be scrutinised through systematic ijtihād to restore the correct balance of values to them.

An adequate coverage of gender justice issues would fall beyond the scope of this article, and what is presented here is, in any case, based on my own synoptic responses to some of the issues raised. I may begin by saying that Islamic family law has encountered obstacles in penetrating entrenched tribal custom prejudicial to women. Some of the factors that come into the picture are not even peculiar to Islamic law and society but constitute challenges of civilisational concern on a global scale. The patriarchal character of human society has generally meant that male dominance infiltrated law and religion as it did the custom and culture of societies in all parts of the globe. In Muslim societies factors such as poverty, low levels of female education and employment, and prevalence of tribalism still constitute formidable challenges to gender equality and family welfare at the dawn of the twenty-first century.

Many Muslim countries have introduced egalitarian laws and constitutions in the post-colonial period, which have had, however, a limited effect on curbing entrenched prejudicial practices concerning women. The problems so encountered often need to be read in the context of their own set of conditions in every country and region. Law reform on women's rights in Southeast Asia and North Africa has been relatively more successful than other regions of the Muslim world. Then there are more specific problems that have adversely affected the healthy growth of Islamic law including, for example, indiscriminate imitation (taqlī $)$ and the consequent decline of original thinking (ijtiha $\bar{d})$ to keep the shari ${ }^{\circ} a h$ abreast with social reality. These problems have been with us for centuries and the clarion call by Jamal al-Din al-Afghani (d. 1898), his disciple, Muhammad 'Abduh (d. 1905), and Muhammad Rashīd Riḍa (d. 1935) at the dawn of the twentieth century for the revival of innovative ijtihād helped to raise awareness of the challenges but has on the whole generated limited results on the revival of ijtiha $\bar{d}$. Muslim jurists continued to a large extent to look back for solutions to current problems in the hallowed works of the imams and jurists of the past. Entrenched patriarchal custom in many parts of Asia, Africa and the Middle East retarded the scope and in many instances hindered the reform of Islamic matrimonial law and inheritance. The "ulama" "s attitude to issues of gender justice also wavered between partial admission and outright denial which only made things more difficult. One can hardly speak of reform to one who denies that gender equality is an issue in the shari ${ }^{\prime} a h$ and that the challenge is only imaginary and non-existent. 
I have elsewhere addressed some of the more detailed juridical issues of gender equality and my purpose here is not to dwell on details but merely to develop a perspective over issues and voice my own views on the challenges before us. This I have presented in the following paragraphs.

\section{What Are the Issues?}

(1) It is submitted that issues of equality and justice for women should be addressed from within the tradition and the prevailing conditions of each society. One should avoid the temptation of putting an Islamic veneer on some foreign ideas which may be altogether unfamiliar to the Muslim law and culture. Muslims should also find their own realistic solutions and not allow the real challenges to get entangled in the heated exchanges of secularist, religious and ultra-conservative debates. To correct the imbalances of history naturally takes time and reflection over the newly emerging issues. Gender equality is also a long term engagement. Windows of opportunity present themselves from time to time and prudent government leaders should be alert to utilise them for society's benefit. Juridical issues of concern to shari $\bar{i}^{\prime} a h$ should be addressed, as far as possible, through imaginative ijtihād that takes a holistic approach to the understanding of scriptural guidelines. Scholastic jurisprudence on gender issues has not been immune to medieval society values that also found their way into the Qur'ān hermeneutics and the ijtihād of some of the leading schools and scholars. To say, for example, that the diyyah (blood money for manslaughter) for a woman is half that of a man simply overturns broader qur'ānic principles on the sanctity of life, on just retaliation (qișāss), and the unqualified and gender blind proclamations on human dignity.

(2) With regard to women's participation in government, one can maintain equality for the most part, with the exception, perhaps, of cases where equality may not be advisable on grounds of judicious policy (siyāsah shar 'iyyah), such as police and military duties in a male dominated environment, or going against the prevailing culture and custom of society. While observance of dominant culture is prudent, yet cultural constraints should be viewed as ad hoc and temporary and be included in the long term campaign for gender justice. My observation on this point is informed by my personal experience of involvement in family law reform in Afghanistan since 2003 and the advice of caution I take is not to risk provocation and protest that can be overwhelming in its negative sweep and can easily render the purpose one fights for even more remote. Gender equality issues should be approached in the true spirit of moderation (wasatiyyah), itself a qur'ānic designation and assignment of the ummah, and seek solutions that strike the middle ground between idealism and reality and between traditional and modern society values. It may be necessary under 
certain conditions to design a two, or even three-phased, approach to equality issues, beginning with the least challenging and proceed toward the more sensitive areas of reform. What is important is follow-up effort and measurable implementation over time. One should avoid the temptation of introducing prescriptive reforms that remain largely unimplemented. I may add further that even in Afghanistan, probably one of the most conservative of all Muslim countries on gender equality matters, I note a growing awareness and support for female education and the importance of women's participation in government and also support for the human rights principles. Such may be the windows of opportunity that prudent political leaders can utilise for people's benefit. What I have said of Afghanistan may not be as relevant for other countries that may have already gone through their own experiences and can afford to aspire to higher levels of refinement.

The only exception of note with regard to women's participation in government concerns the position of the head of state, which is reserved for men based on a presumptive consensus (ijmā), there being no clear authority in the sources to prevent equality even at this level. Our conclusions on this should also be informed by such developments as the prevalence of constitutional checks and balances and separation of powers in modern constitutions, which have altogether altered the material attributes of leadership. Whereas Islamic jurisprudence justified its ruling on this by reference to the position in earlier times of the head of state as leader in jihäd it is doubtful whether the logic of that conclusion can be sustained now due to material changes in the nature of leadership and warfare. It would seem patently inadvisable now for the head of state to lead the army into the battlefield under the present circumstances. ${ }^{4}$ The rules of Islamic jurisprudence also hold that a substantial change in the effective cause and rationale ('illah) of a ruling should be followed by a corresponding change and a suitable ruling $(h u k m)$ through $i j t i h \bar{a} d$.

(3) With regard to women's qualification for appointment to judicial posts, the correct interpretation on this is that of the Qur'ān-commentator Ibn Jarīr al-Tabarī (d. 923) who held, contrary to the prevailing position of the majority, that women are fully qualified for employment to judicial posts. Except for the Hanafĩ school which qualified women to be judges in all disputes outside the prescribed penalties and retaliation cases ( $h u d \bar{u} d$ and qișass), the majority of the leading schools passed negative judgments on this based on a specious analogy drawn with the position of the head of state. Al-Tabarī was right to call this a discrepant analogy (qiyās ma $a l-f \bar{r} r i q$ ) and say that women judges do not necessarily lead the jihād. The principal task of a judge is to comprehend and implement the shari ${ }^{\prime} a h$ and men and women stand on the same footing in this regard. ${ }^{5}$

My recent experience of developments in Afghanistan shows that women themselves can significantly promote their position once they are granted the 
opportunity to do so. In the case of Afghanistan, affirmative action measures that were taken under the 2004 Constitution brought about a significant change. Articles (83 and 84) of this constitution imposed a quota system in favour of women's election to Parliament by stipulating that at least two Members of Parliament in the Lower House (Wolesi Jirga) from each of the 34 provinces must be women. A similar quota was imposed regarding the Upper House (Meshrano Jirga) such that reserved election and appointment of about one-sixth of its total membership for women. These quotas were followed in the September 2005 elections which brought a significant number of women to Parliament. ${ }^{6}$ To compare their presence now (68 and 23 in each of two Houses respectively) with the mere five women that found their way into Parliament in the 1965 election (the last Afghanistan had before the turn of the century) is a milestone of change for the prospects of women empowerment in that country. I am of the view that similar quotas should be followed in the executive and judicial organs of the state. Yet the realities of that country are so compelling that President Karzai, himself a pro-equality figure by his track record, reduced the number of female Cabinet members from three to just one after his victory in the September 2004 elections. There is no female Supreme Court Judge among the nine Judges the President appointed in July/August 2006.

(4) With regard to women's partial disability to act as witnesses in the courts of justice, my enquiry into this led me to the conclusion that there is no clear textual mandate on this in the Qur'ān or authentic ahäaìth. ${ }^{7}$ In view of the unwavering commitment these sources provide on the advocacy of truth and justice, it would be only natural to proceed from this position and say that all avenues that vindicate truth and serve the cause of justice must be left open. If allowing women to give credible testimony in the quest for justice, especially in critical situations where a woman holds vital testimony, one sees no reason why one should impose a prior restriction on her ability to give it. The qur'ānic provision on this occurs in the context of commercial transactions and was informed by the conditions of women in Arabian society at the time. Space does not permit elaboration but when one reads the fuller version of the relevant qur'ānic verse on this subject (2:283), the text itself encourages witnesses to come forth and not to withhold testimony in the cause of justice.

(5) Women enjoy equal rights in the sharī'ah in respect of ownership, management of financial affairs, civil transactions and contracts. The Hanafĩ school has extended this position to the contract of marriage, although the majority of other schools have considered marriage an exception and require its solemnisation by the legal guardian (walī) even of an adult woman. Since Islamic jurisprudence permits selection (takhayyur, or takhyir) among the leading schools, a position which has 
been utilised in the twentieth-century legislation of many Muslim countries, then there is basically no sharī ah-issue of concern in this area. Yet patriarchal customary practices, especially among the tribes, present obstacles to women's enjoyment of their civil and financial rights. The problem here is essentially not juridical but one of prejudicial custom and male dominated society. To give an example, the Qur'ān unequivocally entitles female relatives to specified shares in the inheritance, which is, however, widely denied to them by their male relatives. Statutory enactments in many Muslim countries that banned such practices on pain of imprisonment and fines have not succeeded in curbing entrenched customary positions. The lesson one learns here is that prescriptive law reform needs to be followed by wider campaigns on awareness raising, education and policy initiatives. Muslim women in rural Asia and Africa are not well aware of their rights either under the shari ' $a h$ or statutory law. Legislation should naturally be encouraged and continue to lead the way in the campaign for economic empowerment of women. In some particularly difficult situations, recourse may be had to affirmative action legislation and/or a quota system, for example, in admission to schools and employment centres, on a temporary basis at least, to promote the objectives of equal rights for all citizens.

(6) Some progress has admittedly been made as a result of the Islamic family law reform movement in the latter part of the twentieth century, which brought many ijtiha $\bar{d} d$-oriented changes to aspects of matrimonial law in Muslim countries of the Middle East, Asia and Africa. New civil codes and personal status laws were introduced in the 1950s and 1960s and thereafter which reformed the Islamic law provisions in several areas including the marriage contract, marriageable age limits, polygamy, child custody, divorce, and inheritance. The actual reform measures introduced varied from country to country. Broadly speaking, adult boys and girls were enabled, through the introduction of statutory marriageable age, to contract their own marriage without the intervention of their legal guardian. Polygamy and divorce that had remained as prerogatives only of the male spouse under the fiqh provisions were now both subjected to statutory restrictions and made dependent on obtaining a judicial order. Measures were also introduced on registration formalities as well as the admissible means of proof in matrimonial disputes that were on the whole favourable to women. This phase of family law reform was a marked improvement on the ones earlier incorporated in the Ottoman Mejelle (1876) and Ottoman Family Rights law of 1917.

Whereas the Mejelle legislation was based almost entirely on the Hanafĩ school of law, subsequent reformist legislation envisaged cross fertilisation of ideas and selection (takhayyur) within and among the leading schools of Islamic jurisprudence. The Hanafi law of marriage that entitled adult women to conclude their own marriage contract was thus adopted in non-Ḥanafì countries, and the Mālikī law of 
divorce which allowed greater space for arbitration and validated judicial divorce was similarly adopted in non-Mālikī countries. Some Sunni Muslim countries even adopted provisions of the Shi ite inheritance law that were favourable to female relatives, and opened also the prospects of law reform of the traditional fiqh provisions on bequests in an attempt apparently to ameliorate occasional imbalances in the allocation of shares that occasionally resulted from strict enforcement of the qur'ānic laws of inheritance. The husband power of unilateral talāq was subjected to court order and divorce became in almost all cases subject to court proceedings. Measures were also taken to extend the sharī ah provisions on khul 'divorce that could not be initiated by the wife without the husband's agreement, as was the case under traditional law, but could now be initiated and concluded even without the consent of the husband. The Mālikì law provisions on khul divorce that were more conducive to women's rights were generally adopted even in non-Mālikī jurisdictions. The reform measures so introduced in some cases vested the final

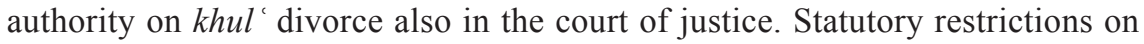
polygamy and divorce actually went beyond the scholastic framework and were based on novel interpretations of relevant passages of the Qur'ān. Muslim jurists across the centuries have also devised additional formulas that can be used to remove possible computational rigidities that can arise in particular combination of circumstances in the administration of estate.

Due to customary and attitudinal constraints that still prevail among Muslim masses, a piecemeal approach to reform of the matrimonial law and inheritance may be preferable to sweeping changes that pose difficulties of implementation. The prospects of a backlash and conservative reaction need to be taken into account even if it means a slow pace for law reform. Democratic and consultative methods, civil society engagement and persuasive media involvement would evidently be needed to ensure receptivity and enforcement.

(7) With regard to the shari 'ah law of inheritance, the pace and scope of reform varied from country to country, and significant as they were, they were minimal in the sphere of inheritance and bequest due mainly to the sensitivity of the subject and the qur'ānic mandates on specific quantities of shares to a number of relatives (mainly of allocation of shares to female relatives: eight out of the total of twelve relatives in the qur'ānic scheme are female). Seen in its historical context, the qur'ānic law of succession significantly strengthened the position of women. Prescribing half share for the female was a forward step in a context when inheritance was only for adult males who were able to fight. Male children and all females were excluded. The early community and Arabian custom did not really appreciate including children and females in the scheme of inheritance. Yet the strong ethico-spiritual bond that the Qur'ān created among the ummah can be seen, perhaps, as a pointer to further 
reform that marks a shift from 'așabiyyah as a criterion of entitlement to the ethicospiritual bond of human equality in the ummah.

The conventional argument given in support of the larger share that men get in inheritance compared to women - namely that men are responsible for providing women with dower, and maintenance both before and after marriage, as well some remedial financial provisions that may help the divorced women - still holds good for the vast majority of women in areas and countries where employment and education opportunities are severely limited for women. The picture is also not always a negative one as Muslim men in many countries and cultures of the Muslim world tend to be on the whole protective of women in the family. We may, nevertheless, draw attention to one or two points on the subject of inheritance as follows:

Bequest can be used, as earlier noted, as a means of adjusting the share allocations in inheritance especially in anomalous situations of inequitable distribution that may be caused by unusual combinations of share allocation. Some instances of computational rigidities under the qur'ānic laws of inheritance have been recorded in the fiqh literature - as also illustrated below in the renowned case of al-Mushtarakah. In such circumstances, the testator enjoys some flexibility with regard to making a bequest and how he or she may choose to use it as a corrective to the possible anomalies of inheritance law. Under the Sunni law of succession, the testator is entitled to make a bequest of up to one third of his or her estate in favour of an outsider, or even a legal heir as under the Shi ite law. Sunni law also permits making bequest to a legal heir with the consent of the other surviving heirs, which the Shi ite law allows even without such consent, provided it does not exceed the limit of one-third. This may be used to address the individual circumstances of a disadvantaged relative, or an outsider for that matter, and thus help to meet the needs of particular situations of real or anticipated imbalance in the distribution of shares. Statutory law in some Muslim countries (Egypt and Tunisia for example) goes as far as to stipulate the obligatory bequest (wașiyyah wäjibah) provision for certain predictable situations where, for instance, orphaned grandchildren, male or female, are precluded from inheritance by the presence of an uncle, who may be a son. What this means is that even in the absence of a bequest by the testator, a bequest will automatically be presumed to have been made in order to address the stipulated circumstances as and when they arise.

Some instances of obvious imbalance in the distribution of inheritance can also be addressed by recourse to the principle of istihsān (equity, juristic preference) especially in cases where strict enforcement of the existing law leads to unfair results. In such situations, istihsān authorises the judge and the jurist to find an alternative and a preferable solution to the case before them that would address considerations of equity and fairness. Notwithstanding the existence of valid precedent on this, as reviewed below, Muslim jurists and judges have not made an effective use of the 
resources of istihsānn. Without wishing to enter details, I may refer here briefly to the renowned case of al-Mushtarakah (the apportioned) which was decided by the caliph 'Umar b. al-Khațāâ. In this case, a woman was survived by her husband, mother, two germane and two uterine brothers. The qur'ānic rules of inheritance were applied but the result was such that the two half brothers received one-third of the estate and the two full brothers were totally excluded. The full brothers complained to the caliph and he decided, after a month of deliberation over the issue with the leading Companions, as the reports indicate, and decided to entitle all the brothers to share equally in the one-third. This is now the standard law.

Unfair results of a similar type can occasionally arise, sometimes due to technical reasons, which could be addressed by recourse to istihsānn, and the judges should not hesitate to do so when istihsān can be invoked to serve the ideals of equitable distribution. ${ }^{8}$ To give an example, suppose that a deceased person is survived by a son and a daughter. During the lifetime of his father the son had bad relations with his father and did not bother to seek his forgiveness even during the months of his last illness, while the daughter took responsibility and spent much of her hard-earned income on her father's medical bills before he died. When this happened the son was quick to claim double the share of his sister in inheritance. This would be the kind of case, in my view, where istihsān can be invoked to remedy the unfair outcome that is anticipated from a strict conformity to the normal rules of inheritance. Yet to the best of my knowledge, Muslim countries have not introduced enabling legislation that would authorise the judge to apply istihsān as a remedial measure - in a manner that would resemble considerations of equity in western jurisprudence. Istihsān admittedly does not seek to introduce new law. It is rather designed so as to address case by case situations where strict implementation of the existing law may lead to unfair results. Istihsān in this way offers some potential to vindicate the cause of equity and fairness when these present a compelling case for reconsideration and review.

Furthermore, some aspects of the Shi ite law of inheritance that are favourable to female relatives can also be adopted by Sunni jurisdictions under the principle of selection (takhayyur) as discussed above. Some Muslim countries of Sunni persuasions have already done so as a part of the law reform measures they have introduced. To the best of my knowledge, the Shi ite law principles on enhancing women's entitlements in certain specified circumstances stand on sound foundations and merit such that offers an ijtihād-oriented option under the principle of takhayyur.

(8) The subject of veiling, or hijāb, has invoked more attention as of late than it merits and has evidently far exceeded its strictly juristic framework. It has become a cultural symbol and a mark of identity, even of protest, for Muslim women living 
in Europe, against the mostly unwarranted demands they have faced for conformity and assimilation to the dominant culture. The situation took a turning for the worse following the former British Foreign Secretary, Jack Straw's comments on the veil in September 2006 and those of the Dutch Immigration Minister, Rita Verdonk, later in November that year to ban the wearing of the burka and face veil in public. More recently in 2010 France introduced a legal ban on the burka, and similar measures are being considered in the Netherlands and elsewhere in Europe. These demands are simply indicative of an over-reaction that goes against Europe's own expressed values so much so that they smack of oppression, but I do not propose to engage into issues. I might add, however, that in Muslim countries too veiling is not always practised for pious reasons but also for conformity to male domination, protection against fundamentalist aggression, even protest against western values.

There is no mandate on veiling (hijāb) and face cover (nijāb) in the Qur'ān and Sunnah. The available evidence in these sources shows that during the Prophet's time, women participated in public life, and most of the women Companions did not practise the hija $\bar{a}$, except for the wives of the Prophet, who began to practise it after the revelation of the qur'ānic verse (33:59) concerning them. Even after this event, other female Companions did not practise the hijäb, as they knew that the qur'ānic directive was addressed to the Prophet's wives only. Women's participation in the life of the community during this time was dignified and social encounters took place at the initiative of men and women as and when the occasion arose. Women were also allowed to take part in congregational prayers and attend the mosques without restrictions.

The Qur'ān advocates modesty and decorum and cautions against provocative behaviour especially in the context of interaction and encounter between the opposite sexes (cf., 7:26, 7:31, 24:30, 24:60, and 33:53). This is the basic message but the text does not specify exactly how modesty is achieved. Modesty is important for the upkeep of moral standards in society, and the Qur'ān has addressed it without any quantitative specifications of the kind that subsequently preoccupied the jurists and cultural trend setters in different times and places. The Qur'ān reminds the believers, men and women alike, to lower their gaze and avoid 'temptatious' behaviour. Covering the body parts during worship and social encounter is treated in the figh writings on 'awrah, on which the leading schools have also recorded differential rulings and interpretations over details. Yet suitable coverage of body parts for purposes of worship and mosque attendance is generally accepted by all the fiqh schools.

Notwithstanding variable customary practices on the uses of $h i j \bar{a} b$ and $n i j \bar{a} b$, these were apparently in use in Iran's Sassanid society prior to the advent of Islam, and segregation of the sexes was in evidence in the Christian Middle East 
and Mediterranean regions at the time of the rise of Islam. During the Prophet's lifetime, as earlier noted, his wives were the only Muslim women required to veil. After his demise and following the Muslim conquests of the adjoining territories, where upper-class women veiled, the veil became a commonplace item of clothing among upper-class Muslim women "by a process of assimilation that no one has yet ascertained in much detail". ' 'Abd al-Ḥalīm Abū Shaqqah's encyclopaedic six-volume work ${ }^{10}$ remains the most exhaustive and acclaimed work on this subject to date. The author entitles his monumental work by the self-explanatory title, Tahrīr al-mar'ah fí 'așr al-risālah (liberation of women during the Prophet's era). He has noted that women's participation in public life is established by no less than 300 hadìths, and it becomes, as such, an approved Sunnah of the Prophet.

The practice of the largely custom-driven phenomenon of veiling in many parts of the Muslim world has become a tool of continued male domination so much so that in some cases a woman is not to be seen outside her marital home; she is not even free to enjoy her recognised rights under the sharì ' $a h$. While the fiqh rules entitle married women to leave their homes to visit close relatives, to seek advice from a learned person as well as for reasons of health and safety, emergency situations and the like, none of these are granted without permission from the husband and male guardian. Islam entitles women to education and dignified work, which are also denied to them, even in parts of the affluent Arab world where opportunities are available. The law in many Muslim countries has yet to address the power of guardianship (wiläyah), which the fiqh texts mainly entrust in male relatives without their being convincing evidence in the sources. Only the Moroccan civil code of 2004, known as the Mudawwanāt al-Usrah, has introduced egalitarian reform on the subject of wilāyah which has taken away the unilateral guardianship powers of the husband over his wife and both are made to stand on equal footing on this. This is because in the language of the Qur'ān wilayyah means mutual friendship and support, just as the Qur'ān also advises that family matters should be determined through consultation and mutual advice. In most other Muslim countries, however, wilāyah not only raises issues over guardianship of minors and decision-making regarding their schooling and place of residence, especially in the event of strained relations between their parents or divorce, but also issues of nationality and citizenship under the statutory law. A woman can hardly pass on her identity under the present law to her minor child, which can in certain situations mean that the child remains stateless with no recognised status under the law. ${ }^{11}$ Some of the challenges of gender equality within the Muslim family thus remain unmet and a shared responsibility exists to respond to them in line with a balanced reading of the normative guidelines of the Qur'ān and Sunnah, and the prevailing conditions of contemporary society. 


\section{Recommendations}

In closing, I propose the following by way of policy-relevant recommendations:

- Reform measures and adjustment of the existing figh rules pertaining to family welfare and women should take their cue from the broader guidelines of the Qur'ān and Sunnah on fairness, human dignity and justice. These and other principles of broader import should not be overshadowed by technical details, customary and historical constraints.

- The principle of selection (takhayyur) and cross fertilisation of ideas among the existing schools of Islamic jurisprudence offer flexibility that merits greater attention in the reform efforts especially of the Islamic laws of inheritance and bequest.

- The principle of istihsān provides much potential in the quest for equitable solutions to instances of technicality and unfair results that arise from the application of the existing law especially in judicial decision-making and particular case scenarios. Notwithstanding reservations over the acceptance of istihsān as a principle of equity expressed by some jurists, especially of the Shāfi 'ì schools, and Imām al-Shāfi 'ì himself, a regulated approach that may now be guided by empowering legislation should encourage the uses of istihsāan in our quest for better solutions to family law issues.

- Addressing entrenched tribal and customary practices prejudicial to women and family require more than prescriptive legislation and fiqh-based ijtihäd. Civil society involvement, action-oriented campaigns and follow-up efforts to realise the fruits of legal reform are equally important.

- Law reform on subjects and areas of family law regulated by the textual ruling of Qur'ān and hadith should only be attempted through sound interpretation and ijtiha $\bar{d}$, and not through modernist legislation that falls short of negotiating the scriptural dispensations.

\section{Notes}

1. Yūsuf al-Qaraḍāwī, "Min al-ghuluww wa 'l-inḥilāl ilā 'l-wasațiyyah wa 'l-i 'tidāl", in: Mu'assasat $\bar{A} 1$ al-Bayt (ed.), Mustaqbal al-islām fì 'l-qarn al-hijrī al-khāmis al- 'ashar (Amman: n.p., 1425 $\mathrm{AH} / 2005), 334$.

2. See for details Mohammad Hashim Kamali, Principles of Islamic Jurisprudence (Cambridge: Islamic Texts Society, 1991; reprint Kuala Lumpur, 1998), 250.

3. See for a discussion Mohammad Hashim Kamali, The Dignity of Man: An Islamic Perspective (Cambridge: Islamic Texts Society, 2002), $5 \mathrm{f}$.

4. For a discussion of the source evidence on reserving the position of the head of state for men see Mohammad Hashim Kamali, Freedom, Equality and Justice in Islam (Cambridge: Islamic Texts Society, 2002), 63-5. 
5. For details on al-Ṭabarî’s view see Kamali, Freedom, 66-70.

6. The Wolesi Jirga currently consists of a total of 269 members and the Meshrano Jirga of 102 Senators. For details on developments in Afghanistan see Mohammad Hashim Kamali, "Islam and Its Shari'a in the Afghan Constitution 2004 with Special Reference to Personal Law", in: Nadjma Yassari (ed.), The Shari'a in the Constitutions of Afghanistan, Iran and Egypt: Implication for Private Law (Tübingen: Mohr Siebeck, 2005), 23-43; idem, "References to Islam and Women in the Afghan Constitution", Arab Law Quarterly 22 (2008), 270-306.

7. Cf., Kamali, Freedom, 66-9.

8. For further details on the various application of istihsān see Mohammad Hashim Kamali, Equity and Fairness in Islam (Cambridge: Islamic Texts Society, 2005), 44f.

9. Cf., Leila Ahmed, Women and Gender in Islam: Historical Roots of a Modern Debate (New Haven and London: Yale University Press, 1992), 5.

10. 'Abd al-Ḥalīm Abū Shaqqah, Taḥrīr al-mar'ah fì 'aṣr al-risālah: Dirāsāt jāmi 'ah li-nușūṣ al-Qur'ān al-Karīm wa Șahīhay al-Bukhārī wa Muslim (Kuwait, 1410AH/1990).

11. For a discussion of the source evidence in the Qur'ān and hadīth on wilāyah (guardianship) see Mohammad Hashim Kamali, Islamic Law in Malaysia: Issues and Developments (Kuala Lumpur: Ilmiah Publishers, 2000), Chapter VI: "Issues over Custody and Guardianship", 105-28. 